Research in Social Sciences

ISSN: 2641-5305

Vol. 1, No. 1 pp.1-8

2018

DOI: $10.53935 / 2641-5305 . v 1 i 1.1$

(C) 2018 by the authors; licensee Academic Publishing Group

\section{Nupe Hegemony in Akokoland in the Nineteenth Century: A Study in Local Imperialism in Pre-Colonial Nigeria, 1845-1897}

\author{
-Johnson Olaosebikan Aremu: Department of History and International Studies, Ekiti State University, Ado-Ekiti, \\ P.M.B. 5363, Ado- Ekiti, Nigeria
}

Sola Opeyemi Oniye: Graduate Student, Department of History and International Studies, Ekiti State University, Ado-Ekiti, P.M.B. 5363, Ado-Ekiti, Nigeria

\begin{abstract}
This paper examined the imperial exploits of Nupe among the Akoko communities of Northeast Yorubaland between 1845 and 1897. The study adopted the narrative and analytical methods of historical research. Data for the study was gathered through primary and secondary sources. These involved oral interviews with some community leaders that were purposively selected. Secondary sources like relevant books, journal articles, newspaper publications and internal materials were also consulted. It noted that one major factor that aided Nupe's successful military imperial raids and subjugation of Akoko area was the lack of unity among the communities. This was itself due to intercommunal warfare in the Akoko region between 1800 and 1845. The wars weakened the local armies and prevented any joint military force against a common enemy, the Nupe. The paper further documented, extensively, the nature of imperial administration established by the Nupe in the Akoko area between 1845 and 1897. Some impacts of Nupe hegemony on Akoko communities during the period of study were also highlighted. The paper concluded that Nupe hegemonic and imperial rule in Akokoland could have continued beyond 1897 if not for the invasion of the British colonial masters.
\end{abstract}

Key words: Akokoland, Nupe, Imperialism, Yoruba, Nigeria

\section{Introduction}

Akokoland is located in the North-eastern part of the Yoruba frontier zone. It is situated in the eastern part of present Ondo State in Nigeria. It comprises about forty-three towns and villages, ${ }^{1}$ with three sources of origin: Ife, Benin and Kabba. ${ }^{2}$ The word 'Akoko' is used to describe the geographical identity and the group of people located in the area.

In the pre-colonial period, there were series of inter-communal warfare with the smaller communities allying with the larger towns during the period of war to fight against their common enemies ${ }^{3}$. However, such alliances never developed into permanent institutional arrangements among the communities involved. ${ }^{4}$ Example of these local wars were those between Ikare and Ikanmu (quarter in Oka); wars waged by Ogbagi

Research in Social Sciences
Vol. 1, No. 1 pp.1-8
2018
DOI: $10.53935 / 2641-5305 . v 1$ Iil.1
"Corresponding Author: Johnson Olaosebikan
Aremu
Email: johnson.aremu@eksu.edu.ng
Funding: This study received no specific
financial support.
Article History:
Received: 2 August 2018
Revised: 5 September 2018
Accepted: 8 October 2018
Published: 6 November 2018
( 2018 by the authors; licensee Academic
Publishing Group

${ }^{1}$ Faboyede Olusanya, "The Akoko Elite, 1900-1960", PhD Thesis, Department of History and International Studies, Ekiti State University, Ado-Ekiti; March, 2013. pp. 29-30

2 NAI: File No. 29667, Vol.1, Intelligence Report Akoko District : Owo Division, Ondo Province

${ }^{3}$ Ibid

${ }^{4}$ S.A. Akintoye, Revolution and Power Politics in Yorubaland 1840-1893: Ibadan Expansion and the Rise of Ekitiparapo, (London: Longman Group Limited, 1971), p. 21 


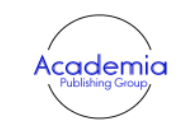

Research in Social Sciences Vol. 1, No. 1 pp.1-8 2018

DOI: 10.53935/2641-5305.v1i1.1

Corresponding Author: Johnson Olaosebikan Агети

Email: johnson.aremu@eksu.edu.ng

Funding: This study received no specific

financial support.

Article History:

Received: 2 August 2018

Revised: 5 September 2018

Accepted: 8 October 2018

Published: 6 Nover 2018

(C) 2018 by the authors; licensee Academic

Publishing Group

$\mid 2$ and Omuo against the smaller towns of those areas; ${ }^{5}$ the Boropa-Oka war and the Ifira - Ipesi war which happened to be the most debilitating of these local wars, being two border towns situated in the frontier between the Akoko and Afenmai areas. ${ }^{6}$ These inter-communal wars weakened the Akoko people and made them vulnerable to external invaders. ${ }^{7}$ These internal wars were followed by external invasions; one of which was that of the Nupe's.

\section{Documenting Nupe Imperial Exploits in Akokoland, 1845-1897: A Brief Survey}

In the nineteenth century, the Nupe beset the northeast Yorubaland. The region besieged by the Nupe included the Yoruba-speaking areas of Yagba, Owe, Bunu, Ijumu and Akoko. ${ }^{8}$ The Nupe war is referred to as the Ogun Anupe or Ogun Tapa among the people. The period 1845-1882 represented the conquest phase, at the end of which the entire northeast Yorubaland was formally brought under Nupe rule, ${ }^{9}$ except Oka Akoko. ${ }^{10}$

Soon after the death of Mallam Dendo in C.1833, an enervating fratricidal war broke out, which prompted Usman Zaki and Masaba, the main protagonists, to seek respite in northeast part of Yorubaland. The warring parties needed both human and material resources to prosecute the war which were all available in northeast part of the Yoruba. This made the conquest and control of the north-eastern part of Yorubaland part of the plan of the warring parties in Nupeland. Between 1878 and 1880, Ndako Damisa led a large force to southern Ijumu, Igbira Okene and Akoko. He, however, suffered a major setback at Oka Akoko ${ }^{11}$ partly because of its hilly nature which was unfit for the ride of horses. The reverses suffered by the Nupe armies in Oka Akoko may also be attributed to the tenacity and determination of the people of Oka. ${ }^{12}$ The assistance received by the Oka Akoko people from an Ado warrior, Aduloju, was another plausible explanation for this development. Aduloju who had once been in league with the Nupe in raiding Akoko towns and villages ${ }^{13}$ broke up the alliance, when the Nupe began to raid in Ado and Ikole direction, located in the eastern part of Ekiti. Aduloju was vexed and immediately ordered his men to turn back the Nupe armies from Ekiti. The murder of Bakare, former chief of Afa, who was a chief guide of Aduloju's forces in Akoko by some Nupe armies, was, however, the straw that broke the camel's back. Aduloju had waited for a chance to disgrace his former allies. The opportunity came when the Nupe forces attacked Oka Akoko. The Oka people invited Aduloju to help them, and Aduloju on the other hand responded and brought his forces to strengthen the defences of Oka. Consequently, the Nupe could not conquer Oka. ${ }^{14}$ In spite of these reverses suffered by the Nupe forces in Oka Akoko, before the demise of Etsu Umaru Majigi of Nupe in 1882, he was able to bring virtually the entire northeast Yorubaland under Nupe hegemony. ${ }^{15}$

In 1875, Umaru Majigi was compelled to return to his capital largely because of the machinations of his rivals who had fanned the ambitions of the Western Nupe king, Baba. Umaru Majigi's energies were drained

\footnotetext{
${ }^{5}$ NAI: File No. 29667, Vol.1, Intelligence Report Akoko District : Owo Division, Ondo Province

${ }^{6}$ C.O. Akomolafe, "The District Head System in Akoko, 1914-1935", ODU: A Journal of West African Studies, New Series, No.18, July 1978. p.28

${ }^{7}$ N.A.I. File No.29667, Vol.1, Intelligent Report Akoko District: Owo Division, Ondo Province.

${ }^{8}$ Z.O. Apata, "The Nupe Imperialism and the Ogidi Grand Alliance 1894-1897: Reflections of Ekitiparapo War", in Adeagbo Akinjogbin (ed.), War and Peace in Yorubaland 1793-1893, (Ibadan: Heinemann Educational Books Nig. Plc,2003), p.431

${ }^{9}$ Ibid, p.432

${ }^{10}$ N.A.I. File No.29667, Vol.1, Intelligence Report Akoko District: Owo Division, Ondo Province.

${ }^{11}$ Z.O. Apata, "The Nupe Imperialism and the Ogidi Grand Alliance 1894-1897: Reflections of Ekitiparapo War", in Adeagbo Akinjogbin (ed.), War and Peace in Yorubaland 1793-1893, (Ibadan: Heinemann Educational Books Nig. Plc,2003), pp.432-434

${ }^{12}$ Michael Mason, "The Jihad in the South: An Outline of the Nineteenth Century Nupe Hegemony in Northern Yorubaland and Afenmai", Journal of the Historical Society of Nigeria, Vol. V. (2), June 1970, p.200

${ }^{13}$ F.O. Bamoyegun, "Akoko-Nupe Relations in the Nineteenth Century", (Ondo State University, Ado-Ekiti: B.A. Long Essay, 1990), p.26

${ }^{14}$ G.O.O. Olomola, "Aduloju of Ado-Ekiti: A Case Study of an Ekiti Warrior Chief of the Nineteenth Century", University of Ife, Ile-Ife: B.A. Long Essay, 1967), p. 28

15 Z.O. Apata, "The Nupe Imperialism and the Ogidi Grand Alliance 1894-1897: Reflections of Ekitiparapo War", in Adeagbo Akinjogbin (ed.), War and Peace in Yorubaland 1793-1893, (Ibadan: Heinemann Educational Books Nig. $\mathrm{Plc}, 2003)$, pp.432-434
} 
by the suppression of Baba's uprising and that of the Kede and others which succeeded it in 1882. Still on campaign, the Etsu (Umaru) died at Lafiagi in June 1882 and was succeeded by Maliki, son of Usman Zaki, who was also a Nupe field officer. Estu Maliki immediately embarked upon the expansionist path of his predecessors, and was Maliki was the last of the nineteenth century Nupe Estus to die while still in power. ${ }^{16}$

The Nupe imperialists appointed loyal officers as agents in Akoko and other places under their hegemony. They included Nupe indigenes, Hausas or loyal returned slaves. These imperial agents were known as ajeles among the Yoruba and azeni among the Afenmai people. The agents were stationed at larger towns and both the smaller and larger towns paid their tribute to the agents. The ajeles (agents) took their share from the tribute collected from the people and also received gifts from the imperialist for the service rendered. ${ }^{17}$

The Ajele possessed so much power as representatives of the etsu in places where the Nupe hegemony extended. Their main duties were to ensure that the people were loyal and pay their tributes to the Nupe imperialist. These agents were rapacious in their tribute collection. At first, the agents collected cowries as tribute from their subjects, but towards the end of 1890, the cowries' holdings of the people had been exhausted; the Ajele started to demand for human beings like children and adults as tribute. ${ }^{18}$

The Ajele/Ogba system adopted by Nupe imperialist was energetically practised by Etsu Maliki who reigned between the periods of 1882-1895. Etsu Maliki, who ascended the throne at the end of the conquest phases, focussed more on making the Nupe administration in the Ajele/Ogba system stronger. Through these, he (Etsu Maliki) accumulated more wealth, and Etsu Maliki's attitude towards payment of much taxes by his subject, made the people to dislike Nupe rule the more. ${ }^{19}$ Sometimes, Akoko markets were raided by the Nupe armies, taking away their goods to meet up the required tax, with women being the most common victims. In order escape the payment of high tax, some of the Akoko people forsook their homes to inaccessible and more secured places. ${ }^{20}$ People under the Nupe hegemony (Akoko, Bunu, Oworo, Yagba and Ijumu) people reached the lowest stage of their resources. As a result of these, the people became more uncomfortable with the Nupe imperialist administration and local revolt against the Nupe became more often and widespread..$^{21}$ Resistance movements against Nupe imperialism was organised by the people with the main aim of putting an end to Nupe rule. ${ }^{22}$ Resistance of the people against their Nupe imperialist was one of the few occasions in which contingents of warriors from a number of villages, and indeed clan-groups, in the area allied together to resist their common enemy. ${ }^{23}$

In 1884, Sonku, a Nupe military commander killed the cow kept in the den of Ayere king (Alayere Ekundina I), which was meant for ritual. The peak of the hostilities was reached when Sonku murdered the messenger sent to him by the Alayere Ekundina, for an explanation. This act of Sonku triggered a revolt in Ayere. Subsequently, Alayere Ekundina (king of Ayere) ordered his people to take up arms and the Nupe camp in Ayere was burn down. Messages were sent to other communities under the Nupe hegemony such as; Ogidi, Aduge, Ogale, Iffe and Akoko imploring them to come together, like the Ekitiparapo, to put an end to Nupe imperialism. It is worthy of note that some Akoko communities were part of the Ekitiparapo alliance

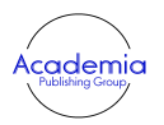

Research in Social Sciences Vol. 1, No. 1 pp.1-8 Vol. 1.18 DOI: 10.53935/2641-5305.v1i1.1 Corresponding Author: Johnson Olaosebikan Агети Email: johnson.aremu@eksu.edu.ng Funding: This study received no specific financial support. Article History:

Received: 2 August 2018

Revised: 5 September 2018

Accepted: 8 October 2018

Published. 6 Novernber 2018

(C) 2018 by the authors: licensee Academic

Publishing Group
${ }^{16}$ Michael Mason, "The Jihad in the South: An Outline of the Nineteenth Century Nupe Hegemony in Northern Yorubaland and Afenmai”, Journal of the Historical Society of Nigeria, Vol. V. (2), June 1970, pp.99-200

${ }^{17}$ Michael Mason, "The Jihad in the South: An Outline of the Nineteenth Century Nupe Hegemony in Northern Yorubaland and Afenmai”, Journal of the Historical Society of Nigeria, Vol. V. (2), June 1970, p.205

${ }^{18}$ Z.O. Apata, "The Nupe Imperialism and the Ogidi Grand Alliance 1894-1897: Reflections of Ekitiparapo War", in Adeagbo Akinjogbin (ed.), War and Peace in Yorubaland 1793-1893, (Ibadan: Heinemann Educational Books Nig. Plc,2003), p.435

${ }^{19}$ Ibid, p.435

${ }^{20}$ Olusanya Faboyede, “Akokoland before Colonial Rule: Earliest Times to 1900", Journal of Arts and Humanities, Vol.4, (1), 13, January, 2015. p.58

${ }^{1}$ Z.O. Apata, "The Nupe Imperialism and the Ogidi Grand Alliance 1894-1897: Reflections of Ekitiparapo War", in Adeagbo Akinjogbin (ed.), War and Peace in Yorubaland 1793-1893, (Ibadan: Heinemann Educational Books Nig. Plc,2003), p.435

${ }^{22}$ Olusanya Faboyede, “Akokoland before Colonial Rule: Earliest Times to 1900", Journal of Arts and Humanities, Vol.4, (1), 13, January, 2015, p.35

${ }^{23}$ Michael Mason, "The Jihad in the South: An Outline of the Nineteenth Century Nupe Hegemony in Northern Yorubaland and Afenmai”, Journal of the Historical Society of Nigeria, Vol. V. (2), June 1970, p.203 


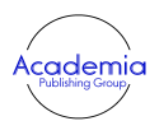

Research in Social Sciences Vol. 1, No. 1 pp.1-8 Vol. 1 .

DOI: 10.53935/2641-5305.v1i1.1

"Corresponding Author: Johnson Olaosebikan Aremu

Email: johnson.aremu@eksu.edu.ng

Funding: This study received no specific

financial support.

Article History:

Received: 2 August 2018

Revised: 5 September 2018

Accepted: 8 October 2018

Published: 6 Nover 2018

(C) 2018 by the authors: licensee Academic

Publishing Group and the incident which led to its formation was still very fresh in their brains. ${ }^{24}$ Another source of discontentment among the people was the dominancy of Obaro of Kabba under the Nupe hegemony. Following the Ogun Igberi, Obaro Kabba work together with Nupe and contributed so much to Nupe colonial expansion in Ijumu and Akoko area. In recognition of his pure loyalty, the Obaro's jurisdiction was extended over Ijumu and Akoko area. The anti-Owe movement was strongly rooted amidst the ethnic groups under Nupe hegemony. ${ }^{25}$ The frequent uprisings in many communities in the northeast Yorubaland under the Nupe authority at that time, makes these communities to conclude that, the only way to destroy Nupe hegemony was by adopting the unity spirit of the Ekitiparapo. In late 1894, the Ogidi grand alliance was formed with primary aim to end Nupe imperialism in their land. ${ }^{26}$

The following communities made up the Ogidi grand alliance: Ogidi, Ayere, Aduge, Ekinrin-Adde, Iffe (Ufe), Ogale-from Ijumu group, Esuku, Oji and Akoko. The Ogidi grand alliance was better organised and formidable. The Alayere stepped aside for Agahun (Agaun) of Esuku, who participated in the Ekitiparapo war and was made the warrior leader of the Ogidi grand alliance, while Alayere became the second warrior leader. Olumodeji of Ayere, Ajakaiye of Ogidi and Ajamba of Oji among others were appointed as the unit commanders of the alliance. The Ogidi grand alliance forces assembled on the defensive Ayinoro hill at Ogidi. ${ }^{27}$ The hill makes the Nupe horses inactive, though the Nupe inflicted so many injuries on the Ogidi grand alliance troops. Nda Jiya, the Maiyaki was relieved of his position as the commander of the Nupe army, because of his inability to break the defences of the Ogidi grand alliance and was replaced by the Makun, Mahammedu, Umaru Majigi's son. ${ }^{28}$ Their old strategies of troubling and starving the opponents to submission became ineffective as they find it difficult to disrupt the supply lines of the Ogidi grand alliance forces. $^{29}$

The Ogidi grand alliance received help from other parts of Yorubaland; particularly from the people of Ekiti. Arms and ammunition were purchased from Lagos and Ekiti. ${ }^{30}$ The Ogidi grand alliance and the Nupe forces were still fighting when the Royal Niger Company (R.N.C.) troops arrived at the scene on 14 January, 1897. ${ }^{31}$ The Royal Niger Company supported the Ogidi grand alliance against the Nupe's, majorly because of their own personal interest. The Royal Niger Company saw the expansion of Nupe imperialism as a threat to the development and expansion of the Royal Niger Company in the Niger-Benue confluence. The military activities of the Nupe interrupted trade in the lower Niger area which greatly affected the interests of the company. ${ }^{32}$

The Royal Niger Company under the leadership of George Goldie saw the option of dislodging the Nupe troops as a way to restore the image of the company. George Goldie attacked the Nupe marched against the Nupe at Kabba with 403 troops and 300 carriers. Makun, Mahammedu, commander of the Nupe army quickly made a retreat to the northerly direction, when he got to known about the Royal Niger Company troops coming after them. George Goldie, leader of the company troops, burnt down the Nupe camp and proclaimed the freedom of the northeast Yorubaland from Nupe imperialism at Kabba town. After the collapse of the

${ }^{24}$ Z.O. Apata, "The Nupe Imperialism and the Ogidi Grand Alliance 1894-1897: Reflections of Ekitiparapo War", in Adeagbo Akinjogbin (ed.), War and Peace in Yorubaland 1793-1893, (Ibadan: Heinemann Educational Books Nig. Plc,2003)pp.436-437

${ }^{25}$ Z.O. Apata, "The Nupe Imperialism and the Ogidi Grand Alliance 1894-1897: Reflections of Ekitiparapo War", in Adeagbo Akinjogbin (ed.), War and Peace in Yorubaland 1793-1893, (Ibadan: Heinemann Educational Books Nig. Plc,2003), p.437

${ }^{26}$ Ibid, pp.435-436

${ }^{27}$ Ibid, p.437

${ }^{28}$ Michael Mason, "The Jihad in the South: An Outline of the Nineteenth Century Nupe Hegemony in Northern Yorubaland and Afenmai", Journal of the Historical Society of Nigeria, Vol. V. (2), June 1970, pp.203-204

${ }^{29}$ Z.O. Apata, "The Nupe Imperialism and the Ogidi Grand Alliance 1894-1897: Reflections of Ekitiparapo War", in Adeagbo Akinjogbin (ed.), War and Peace in Yorubaland 1793-1893, (Ibadan: Heinemann Educational Books Nig. Plc,2003), p.439

${ }^{30}$ Z.O. Apata, "The Nupe Imperialism and the Ogidi Grand Alliance 1894-1897: Reflections of Ekitiparapo War", in Adeagbo Akinjogbin (ed.), War and Peace in Yorubaland 1793-1893, (Ibadan: Heinemann Educational Books Nig. Plc,2003), p.437

${ }^{31}$ Ibid, p.439

${ }^{32}$ Ibid, p.439 
Nupe imperilism, the Ogidi grand alliance was dissolved.$^{33}$ Following the collapse of Nupe imperialism by the troops of the Royal Niger Company in 1897, the leaders of the company took possession of the area and administered it until January 1900, when the charter of the Company was terminated by the British government in 1900, and the British colonial administration, effectively ended Nupe imperialism in Akoko. ${ }^{34}$

\subsection{Impact of Nupe Imperialism on Akokoland}

A failure to examine the impact of Nupe imperialism on Akoko communities would reduce the value of any historical study of Nupe invasion in Akokoland. Nupe imperialism in Akoko left behind indelible marks on the Akoko people as examined below.

\subsection{Religious Impact: Entrenchment of Islamic Religion}

Although there is no reason to disbelieve that there were already Muslims among the Yoruba peoples of the northeast, there is sufficient fact that it was the impact of the nineteenth century jihad, which caused their number to swell to high proportions. Conversions of their subjects were no accident if credence is to be given to Lander who paddled down river through Nupeland in the first decade of the jihadist regime. Travelling along the Niger, he noted:

We found several Falatah (Fulani) Mallams... who have been sent

by the chief of Rabba for the purpose of instructing the natives

in theMohammedan Faith... Whenever they become masters,

the Mohammedan religion follows. ${ }^{35}$

The Islamic religion was followed by the jihadists' flag. Following conquest or submission its continued influence was assured by northern, often Hausa, traders and missionaries, and returned slaves who, while taken away as slaves, had adopted the religion of Islam of their masters. ${ }^{36}$ In the nineteenth century, religion of Islam was introduced into Akokoland through the influence of the Nupe imperialism. During the Nupe invasion in Akoko, among the people taken as captives was (Babarinde Alomoja along with his son) from Iku (a street in Iyometa quarters) in Ikare Akoko. He (Alomoja) was converted into Islam and when he was eventually set free, he was accompanied by some Nupe back to his hometown (Ikare), and to his people at Iku, and started to convert others in the area. Starting from Ikare, the religion of Islam spread to other towns and villages in Akoko. Babarinde Alomoja became the first Imam in Ikare and Akoko as a whole. Due to this reason up till now, the Chief Imam has always been chosen from that same street in Ikare Akoko. ${ }^{37}$

Undoubtedly, the spread of Islam witnessed resistance as the traditional worshippers in Akoko opposed and attacked the Muslims for introducing to the people a religion different from their traditional religion. But with time the opposition ended and the people were allowed to practice religion of their choice. ${ }^{38}$

\subsection{Socio-Cultural Impact}

Nupe imperialism had great effects on Akoko population; it involved the removal of members of the subject communities as slaves. Due to the paucity of data, it is difficult to quote the actual number of slaves that left the area. However, there is no doubt that a substantial number of Akoko able bodied men and women were taken away for slavery and separated from their families.

A common axiom says that if there is war in any area, there must be unrest and all social activities must be grounded to a halt. Akoko was not an exception in the $19^{\text {th }}$ century. The $19^{\text {th }}$ century invasions, most especially the Nupe imperialism, had demographic impact on the Akoko people. During the period, a significant number of Akoko people shifted from one place to another. ${ }^{39}$ While the unconquered Oka Akoko

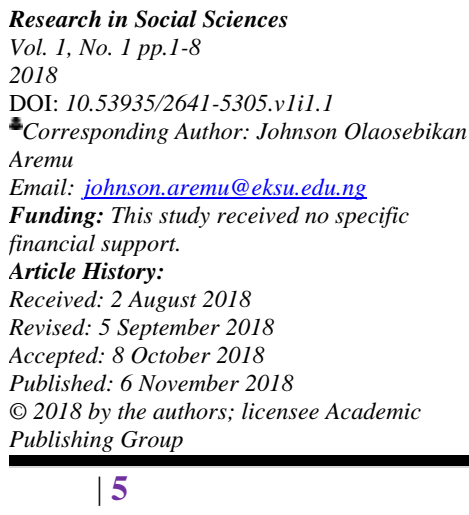

\footnotetext{
${ }^{33}$ Ibid, p.439

${ }^{34}$ Michael Mason, "The Jihad in the South: An Outline of the Nineteenth Century Nupe Hegemony in Northern Yorubaland and Afenmai", Journal of the Historical Society of Nigeria, Vol. V. (2), June 1970, pp.204

${ }^{35}$ Michael Mason, "The Jihad in the South: An Outline of the Nineteenth Century Nupe Hegemony in Northern Yorubaland and Afenmai”, Journal of the Historical Society of Nigeria, Vol. V. (2), June, pp.206-207

${ }^{36}$ Ibid, p.207

${ }^{37}$ Interview with: HRM Oba S.K. Adedoyin, 81 years, Owa-Ale's Chamber, Okorun Street, Ikare Akoko, 10 November, 2016

${ }^{38}$ Interview with: Chief (Mrs) Deborah Agunbiade, 65years, Zaki’s Palace on 3 November, 2016

${ }^{39}$ Interview with: High Chief Olufemi Oguntimehin, 70 years, Okegbagbo Street, Ogbagi Akoko, 12 November, 2016
} 


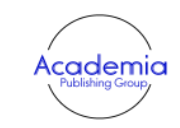

Research in Social Sciences Vol. 1, No. 1 pp.1-8 2018

DOI: 10.53935/2641-5305.v1i1.1

"Corresponding Author: Johnson Olaosebikan Aremu

Email: johnson.aremu@eksu.edu.ng

Funding: This study received no specific

financial support.

Article History:

Received: 2 August 2018

Revised: 5 September 2018

Accepted: 8 October 2018

Published: 6 Nover 2018

(C) 2018 by the authors; licensee Academic

Publishing Group

| 6 possibly fluctuated in population according to the degree of security which prevailed in the surrounding countryside, ${ }^{40}$ other Akoko towns and villages such as Afa-Etioro almost went into extinction due to incessant raids. ${ }^{41}$ Due to the Nupe invasions in Akoko, an appreciable number of people went into exile. For instance, some of the Ikare people went into hiding in places like Owa-Ale's hill. The hill served as a safe abode for the people during the period. ${ }^{42}$ Beelu hill also served as refuge for people of Ekan quarters in Ikare just as the Oka hill served as an edifice of defence for the people of Oka. ${ }^{43}$

Both centralization and decentralization were recognized responses to Nupe military threats in different places. The abandonment of traditional village sites and the dispersion of the villagers were reactions of people unable to defend themselves more effectively. Many villages probably remained dispersed until the Royal Niger Company troops had restrained their Nupe imperialist. ${ }^{44}$ Remnants of Nupe invaders settled in Ikare, leaving their marks on the land and the people. For instance, words like alubosa, seria and dialectal exclamations like hakikia! (Meaning, verily) were indigenised from the Nupe interaction. There is no doubt that Islam greatly influenced the society, especially their names. ${ }^{45}$

\subsection{Political Impact}

Nupe invasion in Akoko had political impact on the Akoko communities. Some of the chieftaincy disputes in Akoko communities were as a result of the Nupe invasion. For instance, the royal rivalry in Arigidi was a good example. During the Nupe imperialism in Akoko, Arigidi was the centre of the Nupe, there was a street known as Isale Tapa inhabited by the Nupe descendants. The ruling power in Arigidi changed from the earlier ruling house to that of the present, claim to be a descendant of Nupe, who adopted the title Zaki (an Hausa word for lion) which is akin to the chieftaincy titles of the Northern people. The earlier ruling house left Arigidi-Oja to settle at Imo-Arigidi. ${ }^{46}$

Another example was that of Ikare royal rivalry, Owa-Ale of Ikare claim that the generations of Olukare were from Nupe who settled in Ikare with the permission of his (Owa-Ale) forefather who was the authentic traditional ruler, prior to the arrival of the Nupe. Owa-Ale argued that, the paraphernalia of office used by the Olukare before now was the wearing of turban in favour of crown and the use of kakaki (long trumpet) which was used by the Nupe's. ${ }^{47}$ Though the Olukare and his supporters denied the claims made by Owa-Ale, and argued that Owa-Ale was a quarter chief in Ikare and to them still remain as one, ${ }^{48}$ and stated the only king in Ikare Akoko is the Olukare of Ikare. ${ }^{49}$ All these are part of the political impact left behind by the Nupe imperialism.

The identity of Akoko towns and villages as part of Yorubaland was affected by the nineteenth century Nupe imperialism. It was as the result of Nupe imperialism on Akoko that the area was placed under Kabba Division in the first eighteen years of British colonial rule. ${ }^{50}$ In the choice of Kabba as the administrative headquarters, the British merely based their conclusion on what they considered as 'the preponderant role of

\footnotetext{
40 Michael Mason, "The Jihad in the South: An Outline of the Nineteenth Century Nupe Hegemony in Northern Yorubaland and Afenmai", Journal of the Historical Society of Nigeria, Vol. V. (2), June, p.208

${ }^{41}$ F.O. Bamoyegun, "Akoko-Nupe Relations in the Ninteenth Century", B.A. Long Essay, Department of History, Ondo State University, Ado Ekiti, June 1990, p.66

42 Interview with: HRM Oba S.K. Adedoyin, 81years, Owa-Ale's Chamber, Okorun Street, Ikare Akoko, 10 November, 2016

43 J. A. Dada, "Refugees in Nineteenth Century Akoko", B.A. Long Essay, Department of History, Ondo State University, Ado Ekiti, June 1987, p.10

44 Michael Mason, "The Jihad in the South: An Outline of the Nineteenth Century Nupe Hegemony in Northern Yorubaland and Afenmai", Journal of the Historical Society of Nigeria, Vol. V. (2), June, p.208

45 J.B. Ogundana, "Ikare", in G.O. Oguntomisin (ed.), Yoruba Towns and Cities, Volume One, (Ibadan: Bookshelf Resources, 2003), p.25

46 J. A. Dada, "Refugees in Nineteenth Century Akoko", B.A. Long Essay, Department of History, Ondo State University, Ado Ekiti, June 1987, p. 15

${ }^{47}$ Interview with: HRM Oba S.K. Adedoyin, 81years, Owa-Ale's Chamber, Okorun Street, Ikare Akoko, 10 November, 2016

${ }^{48}$ Interview with: High Chief S.O. Kutelu, 80years, Okeruwa Street, Ikare Akoko, 10 November, 2016

${ }^{49}$ Interview with: Olori J.I. Momoh, 78years, Olukare Palace, 10 November, 2016

${ }^{50}$ S.T. Okajare, "The Akoko-Yoruba and their Neighbours, 1800-1960: A Study in Inter-Group Relations", PhD Thesis, Department of History and International Studies, Ekiti State University, Ado-Ekiti, 2012, p.157
} 
Kabba' during the Nupe invasion in the last decades of the nineteenth century. During the Nupe imperialism on Akoko, Kukuruku, Kabba and its outlying districts; Kabba was established as headquarters of Nupe local administration. These facts made the British to erroneously believed that Obaro was the head of Akoko as well as other districts contiguous to Kabba. Indeed, it was this false assumption that motivated the British, some years later, to suggest the creation of Kabba Emirate to comprise the above districts with the Obaro of Kabba as its Emir. ${ }^{51}$ Akoko was placed under the Northern Province until 1918, when Akoko District was transferred to the Southern Province in December $1918 .^{52}$

\subsection{Economic Impact}

The Nupe imperialism in Akoko had a devastating effect on the economic development of Akoko people. The economic activities of Akoko were affected, both directly and indirectly by population loss, as many able bodied men and women were carried away as slaves. An emphasis on population loss as such is highly relevant to the question of socio-economic development. Just as population growth played a major role in European development in providing labour, markets, and the pressure which led to further advance. ${ }^{53}$ So also population loss affected the economic development of Akoko people.

During Nupe invasion, high number of Akoko people was carried away as slaves, (most especially able bodied men in their prime age), these prevented the little population that remained from effectively engaging in agricultural, indigenous arts and crafts making. They abandoned their home and occupation and went into hiding. Many towns and villages abandoned their sites and fled up to the hills, for instance, Owa-Ale and Beelu hills in Ikare and Oka hill in Oka Akoko, and some into the forest and hiding places. They put all their effort in ensuring their safety, and these led to decrease in economic development of Akokoland. ${ }^{54}$

\section{Conclusion}

The study discussed Nupe imperialism in Akoko in the nineteenth century. The study reaffirmed that some Akoko communities had waged war against one another in the pre-colonial period, which makes the Akoko people located in the north-eastern part of the Yoruba frontier zone vulnerable to Nupe imperialism. Nupe imperialism in Akoko left behind an indelible mark on the people of Akoko; politically, socially and economically. The Nupe imperialism influenced the infiltration of Islam into the Akoko region. It also had great effect on Akoko population; because it involved the removal of members of the subject communities as slaves, and these greatly affected their economic development, as population is very important for the development of any community.

\section{References}

Akintoye, S.A., (1971). Revolution and Power Politics in Yorubaland 1840-1893: Ibadan Expansion and the Rise of Ekitiparapo. London: Longman Group Limited.

Akomolafe, C.O. (1978). The District Head System in Akoko, 1914-1935. Odu Journal of West African Studies, New Series, No.18, July.

Akomolafe, C.O., (1979). The Establishment of British Administration and its Impact on Owo-Akoko Relations, $1917-$ 1935. Journal of the Historical Society of Nigeria, 10(1).

Apata, Z.O. (2003). The Nupe Imperialism and the Ogidi Grand Alliance 1894-1897: Reflections of Ekitiparapo War, in Adeagbo Akinjogbin (ed.), War and Peace in Yorubaland 1793-1893, (Ibadan: Heinemann Educational Books Nig. Plc).

Bamoyegun, F.O. (1990). Akoko-Nupe Relations in the Nineteenth Century. Ondo State University, Ado-Ekiti: B.A. Long Essay.

Dada, J.A. (1987). Refugees in Nineteenth Century Akoko. B.A. Long Essay, Department of History, Ondo State University, Ado Ekiti.

Research in Social Sciences

Vol. 1, No. 1 pp.1-8

2018

DOI: 10.53935/2641-5305.v1i1.1

Corresponding Author: Johnson Olaosebikan

Aremu

Email: johnson.aremu@eksu.edu.ng

Funding: This study received no specific

financial support.

Article History:

Received: 2 August 2018

Revised: 5 September 2018

Revised: 5 September 2018

Accepted: 8 October 2018

() 2018 by the authors; licensee Academic

Publishing Group

Faboyede, Olusanya, (2013). The Akoko Elite, 1900-1960. PhD Thesis, Department of History and International Studies, Ekiti State University, Ado-Ekiti.

${ }^{51}$ C.O. Akomolafe, "The District Head System in Akoko, 1914-1935", ODU: A Journal of West African Studies, New Series, No.18, July 1978. pp.32-33

${ }^{52}$ C.O. Akomolafe, "The Establishment of British Administration and its Impact on Owo-Akoko Relations, 1917-1935," Journal of the Historical Society of Nigeria, Vol.10, No.1, December 1979, p.67

${ }^{53}$ Walter Rodney, How Europe Underdeveloped Africa, (Abuja: Panaf Publishing, Inc., 2005), p.112.

${ }^{54}$ Interview with: High Chief S.O. Kutelu, 80years, Okeruwa Street, Ikare Akoko, 10 November, 2016. 
Faboyede, Olusanya, (2015). Akokoland before Colonial Rule: Earliest Times to 1900. International Journal of Arts and Humanities, 4(1).

Mason, Michael, (1970). The Jihad in the South: An Outline of the Nineteenth Century Nupe Hegemony in NorthEastern Yorubaland and Afenmai. Journal of Historical Society of Nigeria, 5(2).

Ogundana, J.B., (2003). "Ikare", in G.O. Oguntomisin (ed.), Yoruba Towns and Cities, Volume One. Ibadan: Bookshelf Resources.

Okajare, S.T., (2012). The Akoko-Yoruba and their Neighbours, 1800-1960: A Study in Inter-Group Relations. PhD Thesis, Department of History and International Studies, Ekiti State University, Ado-Ekiti.

Olomola, G.O.O., (1967). Aduloju of Ado-Ekiti: A Case Study of an Ekiti Warrior Chief of the Nineteenth Century. B.A. Long Essay, Department of History, University of Ife, Ile-Ife.

Rodney, W., (2005). How Europe Underdeveloped Africa. Abuja: Panaf Publishing, Inc. 